Ekonomi terhadap Gizi

\title{
PENGARUH FAKTOR EKONOMI TERHADAP GIZI BALITA
}

\author{
Muhammad Ibnu Aksol M, Muhammad Ali Sodik \\ IIK Strada Indonesia \\ akslibnu@gmail.com, alisodik2012@gmail.com
}

\begin{abstract}
Abstrak
Masalah gizi merupakan masalah yang umum di beberapa negara yang sedang berkembang termasuk Indonesia terutama masalah kekurangan gizi. Rendahnya pertumbuhan ekonomi akibat krisis ekonomi yang terjadi menyebabkan meningkatnya insiden kemiskinan di negara ini. Peningkatan insiden kemiskinan sangat memungkinkan berlangsung melalui kenaikan harga-harga (khususnya komoditi makanan) karena depresiasi rupiah yang drastis, kontraksi sektor formal yang kemudian berakibat pada menjamurnya kebangkrutan usaha-usaha ekonomi, meningkatnya penganguran terbuka dan memburuknya prospek pasar kerja di sektor informal perkotaan, dan penurunan drastis produksi pertanian. Kesemuanya itu pada gilirannya berkibat pada penurunan tingkat pendapatan dan daya beli sebagian besar penduduk, khususnya kelompok dengan pendapatan rendah, baik dari daerah perkotaan maupun di pedesaan, rendahnya daya beli masyarakat terhadap makanan menyebabkan semakin besarnya masalah gizi (gizi buruk) khusunya pada balita.

Kata Kunci : Pertumbuhan ekonomi, kemiskinan, status gizi balita.
\end{abstract}

\section{1. latar belakang}

Pembangunan pada hakekatnya merupakan kerjasama antara pemerintah dan masyarakat untuk mewujudkan kesehjateraan. Salah satu keberhasilan dalam pembangunan adalah peningkatan kualitas manusia. Untuk menghasilkan manusia yang berkualitas salah satu faktor yang diperlukan adalah gizi yang baik. Banyak penduduk Indonesia yang menderita gizi kurang. Berdasarkan data Survei Sosial Ekonomi Nasional tahun 2002, masalah gizi kurang pada balita sebesar $27.3 \%$ atau sekitar 5.01 juta balita dan 1.47 juta balita diantaranya menderita gizi buruk. Meskipun keadaan ini lebih membaik jika dibandingkan dari data pada tahun 1998 yaitu 6 juta balita (29.5\%) menderita gizi kurang dan 2.2 juta balita (10.5\%) gizi buruk. Masalah gizi mempunyai dimensi yang luas, tidak hanya berkaitan dengan masalah pangan, kesehatan, dan pengasuhan tetapi juga berkaitan dengan masalah sosial ekonomi, budaya, pendidikan dan lingkungan. Kemiskinan merupakan salah satu faktor penyebab terjadinya masalah gizi kurang di Indonesia. Kemiskinan yang 
dialami dapat membuat masyarakat kekurangan akses terhadap pendidikan, pelayanan kesehatan, pekerjaan, perlindungan terhadap keluarga, serta akses ke pelayanan publik. Salah satu faktor yang berpengaruh terhadap masalah gizi adalah budaya. Faktor budaya dapat mengakibatkan terjadinya masalah kemiskinan yang akan berdampak pada masalah gizi.

\section{Kasus masalah}

Berbagai teori dan kajian telah dilakukan oleh para ahli dalam menelaah masalah gizi dan kesehatan. Dalam teori Blum, status kesehatan dipengaruhi oleh lingkungan, pelayanan kesehatan, perilaku dan factor genetik. Kondisi ini tidak berdiri sendiri dan saling terkait selama masa kehidupan (van Leeuwen, 1999). Selanjutnya, Unicef mengembangkan kerangka penyebab terjadinya masalah gizi dengan menjelaskan keterkaitan masalah gizi dalam berbagai tingkatan factor penyebab seperti tampak dalam diagram 1 (Unicef, 1990). Penyebab mendasar terjadinya masalah gizi adalah kemiskinan dan keterbatasan sumberdaya alam yang akan mempengaruhi struktur ekonomi masyarakat serta kemampuan politik dalam mengatur dan mengontrol ketersediaan sumber daya (manusia dan alam) yang dimiliki oleh suatu Negara. Di negara-negara miskin/sedang berkembang keterbatasan sumberdaya berpotensi terhadap rendahnya tingkat pendidikan masyarakat, yang dinyatakan sebagai penyebab tidak langsung masalah gizi masyarakat. Keterbatasan akses pangan, pendidikan yang rendah, keterbatasan fasilitas pelayanan kesehatan, faktor lingkungan serta rendahnya perhatian kepada anak dan wanita menjadi determinan yang saling terkait. Akhirnya, masalah penyakit dan rendahnya asupan nutrisi secara timbal balik menjadi penyebab langsung rendahnya status gizi masyarakat, baik secara bersamaan ataupun silih berganti dalam lingkaran masalah kesehatan masyarakat. Kasus gizi buruk muncul sebagai manifestasi adanya masalah gizi di masyarakat. Penyebab langsung terjadinya kasus gizi buruk adalah kurang gizi dan penyakit infeksi. Kurang gizi sebagai akibat tidak cukupnya asupan nutrient dapat menurunkan imunitas tubuh sehingga mudah terserang penyakit infeksi. Sebaliknya, bila anak menderita penyakit infeksi maka anak tersebut dapat menderita kurang gizi terlebih bila asupan nutrient dari makanan tidak mencukupi.

\section{Tinjauan pustaka}

Masalah Gizi Balita Balita merupakan kelompok anak yang berada pada rentang usia 0-5 tahun (Adriani dan Wirjatmadi, 2012). Menurut Profil Kesehatan DIY (2018), balita termasuk bayi baru lahir yang berusia 0 sampai menjelang tepat 5 tahun. Saat usia tersebut, balita masih tergantung penuh terhadap orang lain mulai dari asupan makanan, mandi, buang air kecil, buang air besar, dan merawat kebersihan diri. Periode emas atau golden age period merupakan periode yang kritis yang terjadi satu kali dalam kehidupan anak, karena pada masa ini lebih dari 100 milyar sel otak 
siap untuk distimulasi agar kecerdasan anak dapat berkembang secara optimal di kemudian hari. Periode ini terjadi pada 1000 hari pertama, yaitu semenjak kehamilan sampai anak berusia 2 tahun. Anak yang memiliki awal tumbuh kembang baik akan tumbuh menjadi dewasa yang lebih sehat sehingga nantinya akan memiliki kehidupan lebih baik (Sugeng dkk, 2019).

\section{a. Stunting}

merupakan kondisi gagal tumbuh pada anak balita sehingga anak terlalu pendek untuk usianya (Buletin Stunting, 2018). Menurut PMK No.2 Tahun 2020, anak dengan $\mathrm{PB} / \mathrm{U}$ atau TB/U dibawah minus dua standar deviasi (<-2) adalah an(stunted) dan anak dengan $\mathrm{PB} / \mathrm{U}$ atau TB/U dibawah minus tiga standar 10 deviasi $(<-3)$ disebut dengan sangat pendek (severely stunted). Berikut merupakan kategori dan ambang batas status gizi menurut indeks PB/U atau TB/U (PMK Stunting dapat disebabkan oleh beberapa faktor. Faktor yang pertama yaitu faktot genetik. Faktor genetik merupakan modal dasar untuk mencapai hasil akhir proses tumbuh kembang anak. Kualitas dan kuantitas pertumbuhan dapat ditentukan melalui instruksi genetik yang terkandung dalam sel yang telah dibuahi (Soetjiningsih, 2013). Faktor genetik merupakan faktor yang tidak dapat diubah karena berasal dari gen keturunan kedua orang tua (Fikawati, 2017). Pertumbuhan fisik anak dipengaruhi oleh tinggi badan orang tua. Orangtua yang pendek disebabkan oleh kondisi patologi seperti adanya defisiensi hormon pertumbuhan sehingga gen dalam kromosom membawa sifat pendek. Hal tersebut dapat memperbesar peluang anak membawa gen tersebut sehingga termasuk dalam kategori stunting (Nasikhah R dan Margawati, 2012). Penelitian di Mesir Indeks Kategori Status Gizi Ambang Batas Panjang Badan menurut Umur (PB/U) atau Tinggi Badan Menurut Umur (TB/U) Sangat Pendek <-3 SD Pendek -3 SD sampai dengan <-2 SD Normal -2 SD sampai dengan 3 SD Tinggi >3 SD 11 menunjukkan bahwa anak yang lahir dari ibu dengan tinggi badan kurang dari $150 \mathrm{~cm}$ memilliki resiko tumbuh stunting (Solehan, 2012).No.2 Tahun 2020)ak dengan perawakan pendek. Faktor kedua yaitu faktor sosial. Faktor sosial meliputi hubungan kekeluargaan, pandangan pekerja, kebebasan berpolitik, dan hubungan kemasyarakatan (Satiyono dan Bodroastuti, 2012). Faktor sosial yang dapat mempengaruhi kejadian stunting yang pertama adalah ekonomi keluarga. Status ekonomi keluarga yang rendah dianggap memiliki pengaruh yang dominan terhadap status gizi kurus dan pendek. Sebaliknya, keluarga yang memiliki status ekonomi baik dapat menyediakan semua kebutuhan primer maupun sekunder bagi anak. Selain itu, keluarga yang berstatus ekonomi baik juga memiliki akses pelayanan yang lebih baik dibandingkan keluarga dengan status ekonomi rendah. Anak pada keluarga dengan status ekonomi rendah cenderung mengkonsumsi makanan dalam segi kuantitas, kualitas, serta variasi yang kurang. Status ekonomi yang tinggi membuat seseorang memilih dan membeli makanan yang bergizi dan bervariasi (Setiawan Eko dan Rizanda Machmud, 2018). Faktor sosial kedua yang dapat mempengaruhi kejadian stunting yaitu tingkat pendidikan orang tua balita. Tingkat pendidikan orang tua memiliki pengaruh terhadap kesehatan anak, terutama pada status gizi. Seorang orang tua yang tingkat pendidikan tinggi memiliki pengetahuan yang lebih terhadap 
pola hidup sehat dan menjaga kesehatan tubuh. Salah satunya adalah pemilihan bahan makanan yang bergizi dengan jumlah cukup. Tingkat pendidikan dapat mempengaruhi derajat kesehatan. Status pekerjaan kedua orang tua juga merupakan faktor sosial kejadian stunting. Status pekerjaan merupakan jenis kedudukan seseorang dalam melakukan pekerjaan di suatu unit usaha/kegiatan. Seseorang dikatakan bekerja jika melakukan kegiatan ekonomi untuk memperoleh pendapatan maupun keuntungan paling sedikit 1 jam tidak terputus (Badan Pusat Statistik). Pada ibu yang bekerja memiliki waktu yang lebih sedikit dalam memperhatikan asupan makanan anaknya akan tetapi pendapatannya lebih banyak dibandingkan dengan ibu yang tidak bekerja (Rozali, 2016). Dalam penelitian Rozali (2016) mengungkapkan, kehidupan ekonomi pada keluarga dengan ibu yang bekerja akan lebih baik dibandingkan dengan keluarga yang hanya menggantungkan ekonomi pada kepala keluarganya. Kehidupan ekonomi yang lebih baik akan membuat keluarga dapat memberikan perhatian yang layak pada asupan gizi anak. Menurut UndangUndang nomor 13 tahun 2003 tentang Ketenagakerjaan pada pasal 82, dikatakan bahwa pekerja perempuan memperoleh cuti satu setengah bulan 13 sebelum dan satu setengah bulan setelah melahirkan. Pasal 83, pekerja/buruh perempuan yang anaknya masih menyusu harus diberi kesempatan seapatutnya untuk menyusui anaknya. Pasal 84 disebutkan pekerja/buruh yang menggunakan hak cuti tersebut tetap berhak mendapatkan upah yang utuh (Aritonang, 2012).

b. ISPA

Menurut WHO, penyakit ISPA merupakan salah satu penyebab kematian pada anak di negara yang sedang berkembang. Infeksi Saluran Pernafasan Akut (ISPA) diawali dengan panas disertai salah satu atau lebih gejala, tenggorokan terasa sakit atau nyeri saat menelan, pilek, batuk kering atau berdahak (Sri Wahyuningsih dan Sitti Raodhah, 2017). ISPA sendiri dapat dibagi menjadi 3 penyakit yaitu influenza, amandel, dan radang tenggorokan akut (Noor Mutsaqof dan Suryani, 2016).

c. Diare

Diare adalah keadaan seseorang mengalami buang air besar lebih dari 3 kali dalam sehari dengan konsistensi cair atau lunak (Rahman dkk, 2016). Anak yang mengalami diare akan timbul gejala seperti sering buang air besar dengan konsistensi tinja encer atau cair, mengalami tanda dan gejala dehidrasi (ubun-ubun, turgor kulit menurun dan mata cekung, membran mukosa kering), demam, muntah, anorexia, lemah, pucat, perubahan tandatanda vital (nadi dan pernafasan cepat), pengeluaran urine 15 menurun atau tidak ada (Suriadi dan Yuliani, 2010). Menurut (Depkes, 2010), upaya yang dilakukan dalam mencegah diare yaitu pemberian ASI Eksklusif, perbaikan MPASI, menggunakan air bersih, mencuci tangan, mencuci botol susu dengan benar, membuang tinja bayi dengan benar, dan imunisasi campak yang dapat mencegah keparahan diare.

Menurut Pusat Data dan Informasi Kementerian Kesehatan RI (2014), pola menyusui dikelompokkan menjadi 3 yaitu :

a. Menyusui Eksklusif 
Menyusui eksklusif merupakan pemberian ASI dengan tidak memberikan

bayi makanan maupun minman lain, termasuk air putih kecuali vitamin, obat-obatan, mineral tetes, dam ASI perah.

b. Menyusui Predominan

Menyusui predominan merupakan menyusui bayi tetapi pernah memberikan sedikit air atau minuman yang berbasis air misalnya teh.

c. Menyusui Parsial

Menyusui parsial merupakan menyusui bayi serta diberikan makanan buatan selain ASI seperti susu formula, bubur maupun makanan lain sebelum bayi memiliki umur 6 bulan.

\section{Pembahasan}

\section{Faktor-faktor yang Mempengaruhi Gizi Seseorang}

- Faktor Lingkungan Lingkungan yang buruk seperti air minum yang tidak bersih, tidak adanya saluran penampungan air limbah, tidak menggunakan kloset yang baik, juga kepadatan penduduk yang tinggi dapat menyebabkan penyebaran kuman patogen. Lingkungan yang mempunyai iklim tertentu berhubungan dengan jenis tumbuhan yang dapat hidup sehingga berhubungan dengan produksi tanaman.

- Faktor Ekonomi Di banyak negara yang secara ekonomis kurang berkembang, sebagian besar penduduknya berukuran lebih pendek karena gizi yang tidak mencukupi dan pada umunya masyarakat yang berpenghasilan rendah mempunyai ukuran badan yang lebih kecil. Masalah gizi di negara-negara miskin yang berhubungan dengan pangan adalah mengenai kuantitas dan kualitas. Kuantitas menunjukkan penyediaan pangan yang tidak mencukupi kebutuhan energi bagi tubuh. Kualitas berhubungan dengan kebutuhan tubuh akan zat gizi khusus yang diperlukan untuk petumbuhan, perbaikan jaringan, dan pemeliharaan tubuh dengan segala fungsinya.

- Faktor Sosial Budaya Indikator masalah gizi dari sudut pandang sosial-budaya antara lain stabilitas keluarga dengan ukuran frekuensi nikah-cerai-rujuk, anak-anak yang dilahirkan di lingkungan keluarga yang tidak stabil akan sangat rentan terhadap penyakit gizi kurang. Juga indikator demografi yang meliputi susunan dan pola kegiatan penduduk, seperti peningkatan jumlah penduduk, tingkat urbanisasi, jumlah anggota keluarga, serta jarak kelahiran. Tingkat pendidikan juga termasuk dalam faktor ini. Tingkat pendidikan berhubungan dengan status gizi karena dengan meningkatnya 8 pendidikan seseorang, kemungkinan akan meningkatkan pendapatan sehingga dapat meningkatkan daya beli makanan. 
- Faktor Biologis/Keturunan Sifat yang diwariskan memegang kunci bagi ukuran akhir yang dapat dicapai oleh anak. Keadaan gizi sebagian besar menentukan kesanggupan untuk mencapai ukuran yang ditentukan oleh pewarisan sifat tersebut. Di negaranegara berkembang memperlihatkan perbaikan gizi pada tahuntahun terakhir mengakibatkan perubahan tinggi badan yang jelas.

Akibat yang Ditimbulkan Karena Gizi Salah (Malnutrisi).

Gizi salah berpengaruh negatif terhadap perkembangan mental, perkembangan fisik, produktivitas, dan kesanggupan kerja manusia. Gizi salah yang diderita pada masa periode dalam kandungan dan periode anak-anak, menghambat kecerdasan anak. Anak yang menderita gizi salah tingkat berat mempunyai otak yang lebih kecil daripada ukuran otak rata-rata dan mempunyai sel otak yang kapasitasnya $15 \%-20 \%$ lebih rendah dibandingkan dengan anak yang bergizi baik. Studi di beberapa negara menunjukkan bahwa anak yang pernah menderita gizi salah, hasil tes mentalnya kurang bila dibandingkan dengan hasil tes mental anak lain yang bergizi baik. Anak yang menderita gizi salah mengalami kelelahan mental serta fisik, dan dengan demikian mengalami kesulitan untuk berkonsentrasi di dalam kelas, dan seringkali ia tersisihkan dari kehidupan sekitarnya.

Anak yang berasal dari keluarga dengan tingkat sosial ekonomi rendah telah diteliti memiliki persentase di bawah ukuran normal bagi tinggi dan berat badan anak sehat. Sedangkan hubungan antara zat gizi dan produktivitas kerja telah dikenal baik sejak satu abad yang lalu oleh orang-orang yang mempunyai budak belian yang melihat bahwa gizilah berarti penurunan nilai modal. Produktivitas pekerja yang disiksa atau mendapat tekanan akan memberikan hasil yang lebih rendah bila dibandingkan dengan keadaan yang diurus dengan baik, dalam artian diberikan makanan yang bergizi cukup baik. Gizi salah merupakan sebab-sebab penting yang berhubungan dengan tingginya angka kematian di antara orang dewasa meskipun tidak begitu mencolok bila dibandingkan dengan angka kematian di antara anak-anak yang masih muda. Dampak relatif yang ditimbulkan oleh gizi salah ialah melemahkan daya tahan tehadap penyakit yang biasanya tidak mematikan dan perbaikan gizi adalah suatu faktor utama yang membantu meningkatkan daya tahan terhadap penyakit. Status gizi juga berhubungan langsung dengan lamanya waktu yang diperlukan untuk penyembuhan setelah menderita infeksi, luka, dan operasi yang berat.

\section{Kesimpulan}

1. Status sosial ekonomi keluarga berpengaruh langsung positif terhadap status gizi anak usia dini.

2. Status sosial ekonomi keluarga berpengaruh langsung positif terhadap pola makanan keluarga, artinya perubahan Status sosial ekonomi keluarga akan mengakibatkan peningkatan kualitas pola makan.

3. Status sosial ekonomi keluarga berpengaruh langsung positif terhadap gaya hidup keluarga, artinya peningkatan status sosial ekonomi keluarga akan mengakibatkan perubahan gaya hidup keluarga. 
4. Keluarga merasakan kondisi kekurangan ekonomi dikarenakan penghasilan kecil dan tidak pasti, penyebabnya adalah jenis pekerjaan yang kurang produktif. Pembelanjaan pangan dan mempriotitaskan pembelanjaan masih kurang memenuhi kebutuhan gizi balita. Pelestarian budaya pemberian sumbangan pada anggota masyarakat yang melangsungkan hajatan berpotensi menurunkan kemampuan keluarga untuk belanja pangan.

\section{Daftar pustaka}

https://sehatnegeriku.kemkes.go.id/baca/blog/20170216/0519737/status-gizibalita-dan-interaksinya/

https://jurnaldikbud.kemdikbud.go.id/index.php/ipnk/article/view/337

Kusumaningrum, N. R. (2003). Pengaruh tingkat pendidikan ibu, aktivitas ekonomi ibu, dan pendapatan keluarga terhadap status gizi balita di Kecamatan Simo, Kabupaten Boyolali.

CRIE HANDINI, M. Y. R. N. A. W. A. T. I., \& DEWI, A. C. Pengaruh Pengetahuan Gizi, Status Sosial Ekonomi, Gaya Hidup Dan Pola Makan Terhadap Status Gizi Anak (Studi Kausal Di Pos Paud Kota Semarang Tahun 2015). JURNAL PENDIDIKAN USIA DINI.

Tule, A. R., Siyoto, S., Dwianngimawati, M. S., \& Sodik, M. A. (2018). The Analysis Factors Affecting Interest In Medication Of Receipt Help Aid Bpjs Participant In Balowerti Public Health Center Kediri City. Journal of Global Research in Publich Health, 3(1), 68-75.

Sodik, M. A., Yudhana, A., \& Dwianggimawati, M. S. (2018). Nutritional status and anemia in islamic boarding school adolescent in Kediri City East Java Indonesia. Indonesian Journal of Nutritional Epidemiology and Reproductive, 1(3), 172-176.

Sodik, M. A., Astikasari, N. D., Fazrin, I., Chusnatayaini, A., \& Peristiowati, Y. (2018). Dental health child with retardation mental and parents behavior. Indian Journal of Physiotherapy and Occupational Therapy-An International Journal, 12(4), 278-282.

Sodik, M. A. (2016). Leprosy Patients in public perception: A qualitative study of patient confidence (dis) in the Community. Journal of Global Research in Public Health, 2(1), 82-89.

Siyoto, S., \& Sodik, M. A. (2015). Dasar metodologi penelitian. Literasi Media Publishing. 